九州大学学術情報リポジトリ

Kyushu University Institutional Repository

Occurrence of Parendaeus abietinus (Coleoptera: Curculionidae: Ochyromerini) in Kyushu, Japan and Its Host Range

Tokuda, Makoto

Kojima, Hiroaki

Yukawa, Jun-ichi

https://doi.org/10.5109/2640

出版情報 : ESAKIA. 40，pp.37-39，2000-03-31. Entomological Laboratory，Faculty of Agriculture， Kyushu University

バージョン：

権利関係 : 


\title{
Occurrence of Parendaeus abietinus (Coleoptera: Curculionidae: Ochyromerini) in Kyushu, Japan and Its Host Range*
}

\author{
Makoto TOKUDA, Hiroaki KoJIMA and Junichi YUKAWA
}

\author{
Entomological Laboratory, Faculty of Agriculture, \\ Kyushu University, Fukuoka, 812-8581 Japan
}

\begin{abstract}
The occurrence of Parendaeus abietinus in Kyushu is reported for the first time, and its potential for outbreak is discussed. In addition to a previously known host, Abies homolepis, a congeneric tree species Abies firma was newly regarded as a host plant of the weevil.

Key words: Coleoptera, Curculionidae, Parendaeus abietinus, Abies, distribution record, host record, Kyushu.
\end{abstract}

\section{Collection Records}

Parendaeus abietinus Kojima \& Morimoto, 1996 is a small weevil, which has been recorded from some localities in Honshu and Shikoku (Kojima \& Morimoto, 1996) (Table 1). Yamashita (1978) applied a name Nanophyllobius yamashitai Nakane to this weevil, but that name is invalid since there is no original description of the weevil.

The adults of this weevil have been captured on the leaves of Abies homolepis Sieb. et Zucc. (Pinaceae), which the larva inhabits as a leaf-miner (Kojima \& Morimoto, 1996). Some adults were captured around the leaves of Picea jezoensis Carr. var. hondoensis Rehd., and Larix leptolepis Gord., but these collection records from Picea and Larix are dubious (see below).

Abies homolepis is distributed in mountain areas (700-2000 $\mathrm{m}$ high) of Honshu and Shikoku, and its congeneric relative, Abies firma Sieb. et Zucc. is distributed in upland of Honshu, Shikoku, and Kyushu (Farjon, 1990). Such a wide distribution pattern of Abies trees has made us expect the discovery of this weevil from Kyushu sooner or later, and finally we confirmed the existence of this species in Kyushu as we have expected (Table 1). First we found, in the collection of Hikosan Biological Laboratory, Kyushu University, a specimen of $P$. abietinus that had been collected in 1978 at Mt. Hikosan, Fukuoka Prefecture, northern Kyushu. Thereafter, H. Kojima, the second author, collected this weevil from A. firma in Miyazaki Prefecture, southern Kyushu. More recently, M. Tokuda and J. Yukawa found old mines of this species together with scars of adult feeding on the leaves of A. firma on Mt. Hikosan. Later, M. Tokuda and J. Yukawa observed many adults feeding on, and larvae mining in, the leaves of A. firma at Mt. Unzen, Nagasaki Prefecture, western Kyushu. Thus in this paper we record the existence of $P$. abietinus in Kyushu, for the first time, and remark that it is widely distri-

\footnotetext{
* Contribution from the Entomological Laboratory, Faculty of Agriculture, Kyushu University, Fukuoka (Ser.5, No.41).
} 
buted in Japan except Hokkaido. In addition, A. firma is noted as a new host plant of the weevil.

\section{Potential for Outbreak}

According to Katsura Morimoto (2000, personal communication), a large number of adults were collected from A. homolepis in 1970 at various localities in Shikoku and in 1972 at Ohdaigahara, Nara Prefecture, central Honshu. In 1993, H. Kojima collected 109 individuals at one time in Mezurudaira-Tengukohgen, Shikoku. These data suggest that $P$. abietinus may have a potential for outbreak and becoming a serious pest of Abies stands. Actually some Abies trees were observed dying at Mt. Unzen, probably due to the infestation by this weevil together with other pests.

\section{Host Range}

In addition to $A$. homolepis, there are collection records of many individuals from $P$. jezoensis var. hondoensis at Ohdaigahara in 1984. It is, however, unlikely that $P$. jezoensis is a host plant, since the adults and larvae have never been confirmed feeding

Table 1. Collection records of Parendaeus abietinus from various localities in Japan.

\begin{tabular}{|c|c|c|c|c|c|}
\hline & Prefecture & Locality & Year & Collector & Specimens \\
\hline \multirow[t]{6}{*}{ [Honshu] } & Nagano & Inago, Koumi-machi & 1961 & Y. Ariga & 6 \\
\hline & Nara & Ohdaigahara & 1954 & Y. Shibata & 2 \\
\hline & & & 1972 & F. Kobayashi & 4 \\
\hline & & & 1984 & A. Amagasu & 14 \\
\hline & Wakayama & Mt. Gomanodanzan & 1976 & H. Hiramatsu & 1 \\
\hline & Yamanashi & Masutomi & 1957 & S. Kimoto & 1 \\
\hline \multirow[t]{7}{*}{ [Shikoku*] } & Ehime & Komenono & 1976 & Y. Notsu & 1 \\
\hline & & Mt. Ishizuchi & 1958 & T. Ishihara et al. & 1 \\
\hline & & & 1993 & H. Kojima & 19 \\
\hline & & Mezurudaira-Tengukohgen & 1993 & H. Kojima & 109 \\
\hline & & Omogokei & 1993 & H. Kojima & $\therefore 1$ \\
\hline & Kochi & Kuroson, Tosa & 1956 & T. Hidaka & 1 \\
\hline & Tokushima & Mt. Tsurugisan & 1993 & H. Kojima & 6 \\
\hline \multirow[t]{3}{*}{ [Kyushu] } & Fukuoka & Mt. Hikosan & 1978 & K. Takeno & 1 \\
\hline & Miyazaki & Ebinokohgen & 1997 & H. Kojima & 13 \\
\hline & Nagasaki & Mt. Unzen & 1999 & M. Tokuda et al. & 5. \\
\hline
\end{tabular}

* Thirteen specimens of $P$. abietinus are kept in the collection of Entomological Laboratory, Kyushu University. The labels show that these specimens were collected in the forest of A. homolepis and forwarded in 1970 to the laboratory from Ochi who was working for Shikoku Branch, Forest and Forest Products Research Institute, but do not indicate the name of locality. 
on this plant and the genus Abies is known to be phylogenetically apart from the genus Picea in the family Pinaceae (Frankis, 1989; Farjon, 1990). Therefore they might be collected accidentally in a $P$. jezoensis stand where some $A$. homolepis trees were possibly growing mixed.

According to the collection record by Y. Ariga in 1961, this weevil was captured from L. leptolepis as well as from A. homolepis in Nagano Prefecture. However, he did not distinguish between these plants when he collected this weevil. Katsura Morimoto (2000, personal communication), who identified this weevil, considers that L. leptolepis should be excluded from the host plants of $P$. abietinus, because he has never found the adults on this tree during his long career.

Thus, A. homolepis and A. firma are regarded as only host plants of $P$. abietinus at present.

\section{Acknowledgments}

We wish to thank Dr. K. Morimoto (Emeritus Prof., Kyushu University) for offering us useful information. Our thanks are also due to Messrs. M. T. Chûjô and K. Takeno (Former Staff of Hikosan Biological Laboratory) for allowing us to examine the collection and Dr. R. T. Thompson (The Natural History Museum, London) for his kind reading of manuscript.

\section{References}

Farjon, A., 1990. Pinaceae. 330pp. Koelts Scientific Books, Königstein.

Frankis, M. P., 1989. Generic inter-relationships in Pinaceae. Notes Roy. Bot. Gard. Edinburgh, 45: 527-548.

Kojima, H. \& K. Morimoto, 1996. The tribe Ochyromerini (Coleoptera, Curculionidae) of Japan III. Genera with seven segments in the funicle and key to genera. Jpn. J. Ent., 64: 733-743.

Yamashita, Z., 1978. [Searching for insects on trees in forest]. Shizen, 33: 54-63. (In Japanese) 
